臨 床

\title{
両側感音難聴にて発症した一側皮質性難聴例
}

\author{
日比野 浩・土井 勝美・久保 武・熊谷 晴美*
}

\section{A Case of Bilateral Sensorineural Hearing Loss Associated with Unilateral Infarction of the Auditory Cortex}

\author{
Hiroshi Hibino, Katsumi Doi and Takeshi Kubo \\ (Osaka University) \\ Harumi Kumagaya \\ (National Cardiovascular Center)
}

\begin{abstract}
A patient with bilateral sensorineural hearing loss on a pure tone audiogram (PTA), associated with unilateral (right side) cerebral infarction in the auditory cortex is described. The PTA on the left (contralateral) side initially showed a "scale out". The PTA threshold improved rapidly, and finally returned to almost normal levels within 2 months. The PTA on the right side initially showed mild sensorineural hearing loss. The PTA threshold gradually returned to normal levels within 2-3 months. In contrast to the rapid recovery of the PTA threshold, the maximum speech perception ability on the left side showed a very low score during the follow-up period of 2 years, and showed little improvement. The maximum speech perception ability on the right side maintained a high score from the time of first examination. All of the objective auditory examinations, including the auditory brainstem response (ABR), oto-acoustic emission (OAE), electrocochleogram (ECoG), middle latency response (MLR), and slow vertex response (SVR), indicated that hearing loss on the left (contralateral) side was closely associated with unilateral (right side) cerebral infarction of the auditory cortex. These results suggest that sensorinueral hearing loss on the PTA could be detected at the early stages of onset, even after unilateral damage to the auditory cortex.
\end{abstract}

Key words : cortical hearing loss, unilateral, auditory cortex

\section{はじめに}

人や動物の 1 次聴覚野は側頭葉の Heschl 脳回に存在 し，その聴覚野が脳梗塞などにより両側性に障害される

と, 両側性高度難聴を発症することが知られている(い わゆる皮質性襲)。一側性の聴覚野障害による皮質性難 聴に打いては, 純音聴力検查での聴取域值はほぼ正常範 囲内に保たれ，一方，語音聴力検査にて言語聴取能の低
下が観察されることが特徵的とされてきた1) 3).

一側の内耳より大脳皮質聴覚野に至る聴覚层導路は， 各中継神経核に执いて左右で交叉を繰り返し，両側の大 脳皮質聴覚野に投射する.内耳から聴覚野への情報伝達 は対側優位であり，右利きの人では，右耳からの聴覚情 報は言語中枢の存在する側である左聴覚野に優位に入力 され，逆に，左耳からの情報は右聴覚野に優位に入力さ 
れる、従って, 一側性の大脳聴覚野障害に执いては, 純 音聴力検査は正常で, 語音聴力検查では, 言語中枢の優 位側・非優位側との関連にて, 皮質障害側の対側に抢い て言語聴取能の低下が観察されると報告されてきた。

今回我々は, 脳梗塞を原因とする一側性の皮質聴覚野 の器質的・機能的障害により, その初期には純音扣よび 語音聴力检查の両方にて高度難聴を示し, その後, 急速 に純音聴力検查は正常化したものの, 言語聴取能が低下 したままにて固定した症例を経験したので報告する。

\section{症例}

症例：66歳, 右利き, 男性.

主訴：両側難聴.

家族歷：両親は脳梗塞にて死亡.

既往歷：57歳時, 右耳鳴を訴光近医耳鼻咽喉科受診 し，純音聴力検査を施行するも両側正常であった。60歳 時, 心筋梗塞の発作步り。

現病歴：62歳時, 右上前頭回上り上側頭回の梗塞によ り, 軽度の復唱障害が残存し, 某病院にて経過锶察をし ていた。この時点では難聴の自覚はなかった。平成 6 年

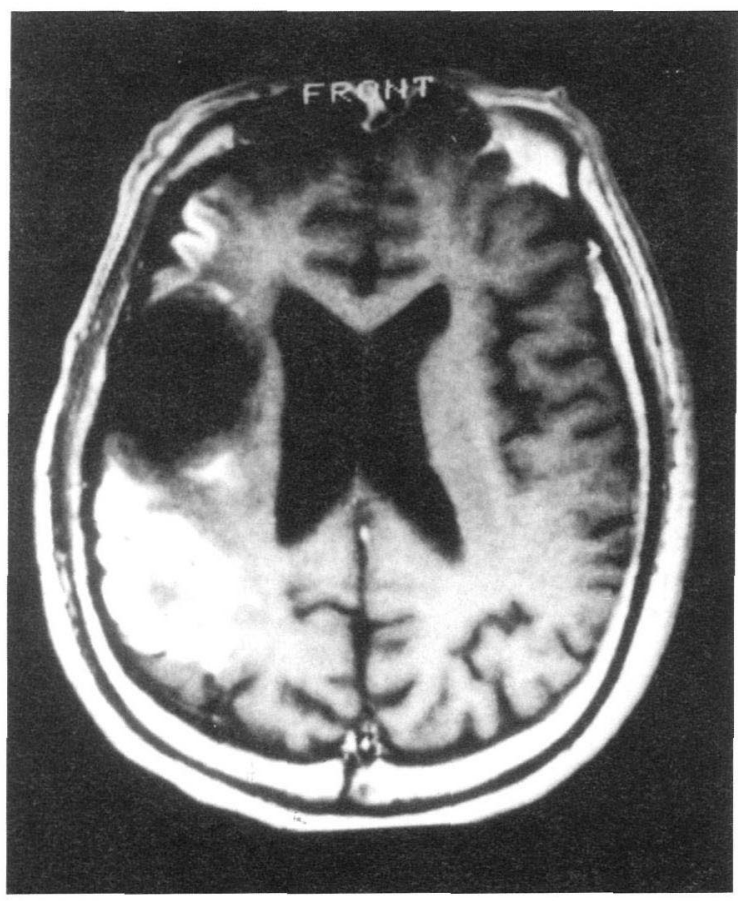

6 月 9 日, 11 日と 2 度の脳梗塞発作があり, 左片麻痺を 認めた。某病院脳内科を受診し, 片麻疩以外に, 強い復 唱障害之字性錯語がめり, 同時に, 両側の難聴(左>右) を自覚したため, 同病院耳鼻科から 7 月 14 日当科入紹介 された，梗塞発症時, 聴覚失認, 純粋語襲, 環境音の認 知障害, 方向弁別障害などは認めなかった.

初診時現象：意識は明瞭で左側の片麻瘏を認めた。耳 鼻咽喉科的な異常所見は認めず, 復唱障害, 字性錯語は 回復し, 発語障害は消失していた。

検查所見：

1 ) 画像検查 : MRI では, 前回の右上前頭回上り上 側頭回の梗塞巣に上る変化とともに, 右側の中側頭回か ら頭頂葉にかけて新たな梗塞巣が観察された(図 1 )。耳 X線上, 内耳道己含めて異常所見は認めなかった。

2 ) 純音聴力検查: 某病院耳鼻科初診時 ( 6 月 21 日), 発症 1 力月後の当科初診時 ( 7 月 14 日), 約 1 力月半後 ( 7 月26日), 2 力月後 ( 8 月 1 日) での純音聴力の変化を示 す(図 2).6月21日の時点では, 右側は平均聴力レベル $42.5 \mathrm{~dB}$ の感音性難聴を示し，左側は襲であった。气の 後, 左側聴力は急速な回復を示し, 2 週後の 8 月 1 日に

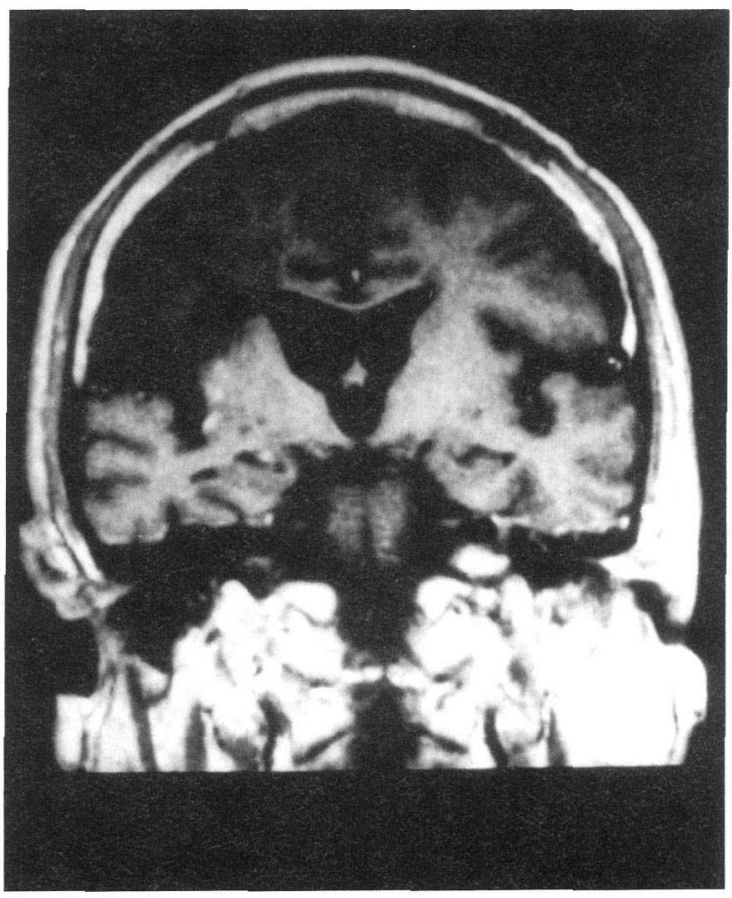

b

図 1 発症直後の MRI T1 強調画像 a) 水平断面, b ) 冠状断面. 


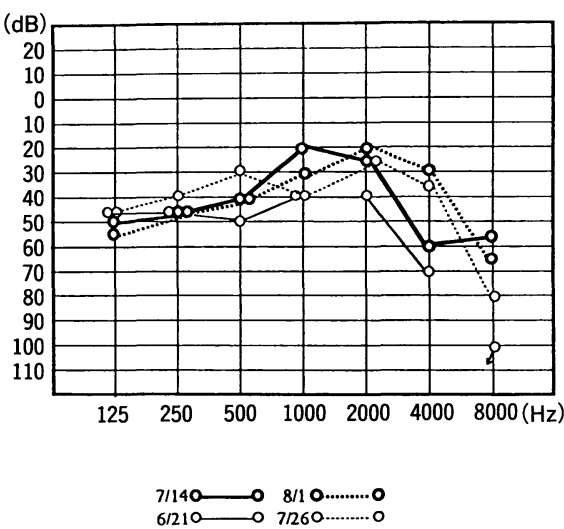

右

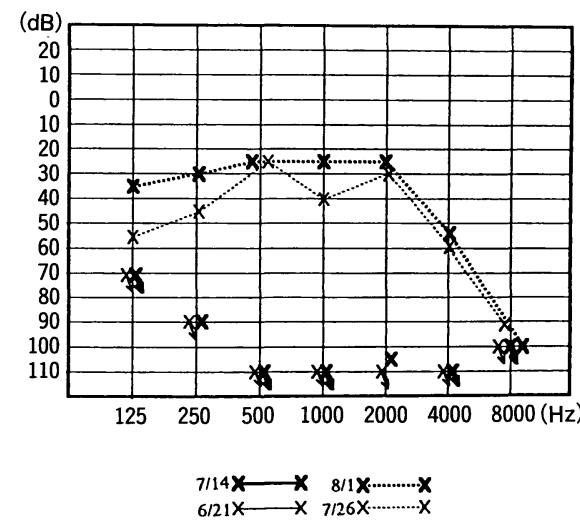

左

図 2 発症後早期 ( 2 力月以内) の純音聴力検査の経時的変化

は $25 \mathrm{~dB}$ と，4〜8 kHz を除いて正常化した．右側聴力 の回復はより緩徐で， 8 月 1 日の時点での平均聴力レベ ルは $26.3 \mathrm{~dB}$ であるが， $500 \mathrm{~Hz}$ 以下の改善は不良であ り，低周波数域の聴力が完全に正常化したのは10月13日 であった. 全経過中, 気導一骨導差は認められなかった.

3）自記オージオメトリー：7 月29日に施行するが, 左右ともに Jerger I 型を示し，補充現象陰性であった.

4 ) 語音聴力検査 : 語音聴力検查上の最高明瞭度の経 時的变化を観察すると(図 3 ), 右側は, 経過中を通じて, $80 \%$ 前後の良好な明瞭度を維持していた。一方，左側の 明瞭度は，全経過中にわたり不良であり，純音聴力が $33.8 \mathrm{~dB}$ に回復した 7 月 29 日の検査時にても，最高明瞭 度 $25 \%$ と低下したままであった．語音聴力検査での最高 明瞭度と純音聴力検查での平均聴力レベルの経時的な変 化を観察すると（図 3 ), 左側に打いて, 両者の解離が著 明である。

$5)$ 耳音響放射 $(\mathrm{OAE})$ 検査：7月29日施行時, 両側 ともに 1 6 kHz の範囲で noise flow 上に distortion product (DP) OAE の反応が得られた（図 4 )。しかし，右 側では, 左側に比較して, total echo power の軽度の低 下が認められた. $3 \mathrm{kHz}$ での echo power の dip は測定 室でのプロープ特性を反映するものである.

$6)$ 蝸電図 $(\mathrm{ECoG})$ 検査: 8 月 11 日施行時の $80 \mathrm{~dB}$ $\mathrm{nHL}$ クリック刺激にて得られた反応波形を示す(図 5 ). 右側では, 蝸牛神経複合活動電位 (AP) 潜時の延長と AP 振幅の軽度低下が認められた。陰性加重電位 (-SP) の増大は認められず, 内リンパ水腫の存在は否 a
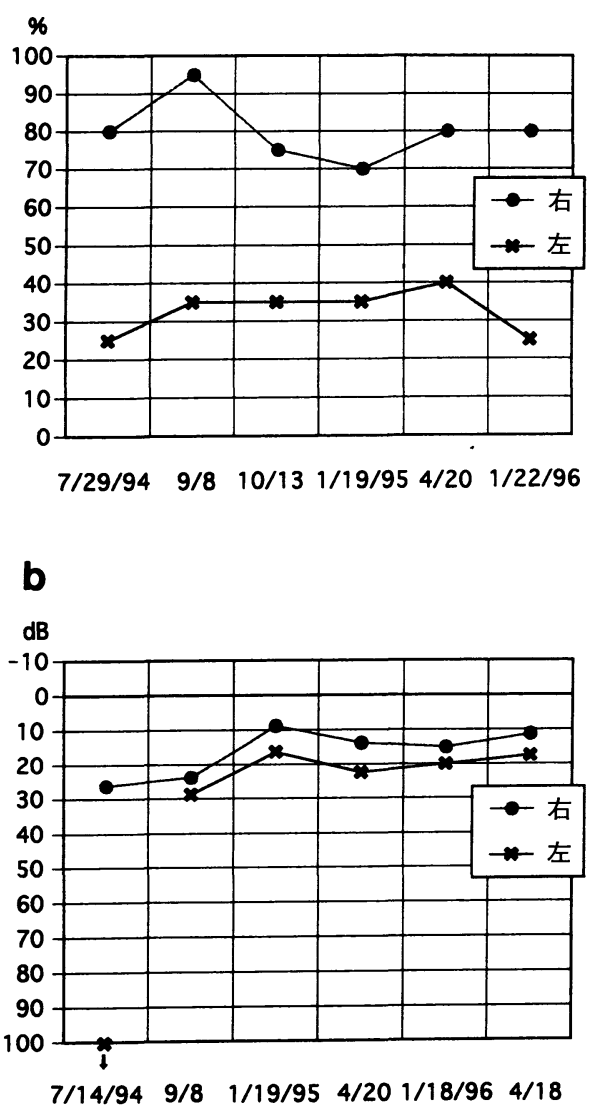

図 3 語音聴力検査での最高明瞭度 ( a ) と純音聴力検査での平 均聴力レベル $(\mathrm{b})$ の経時的変化 


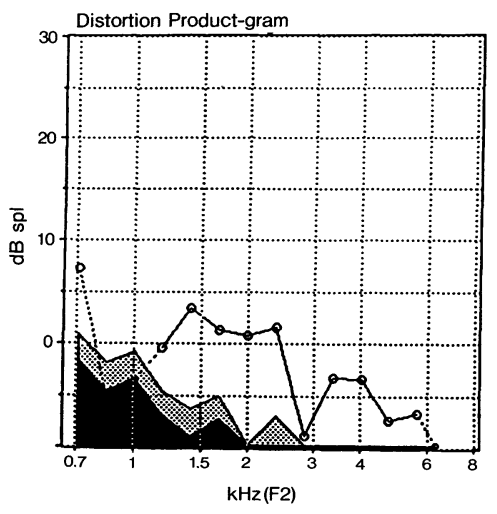

右

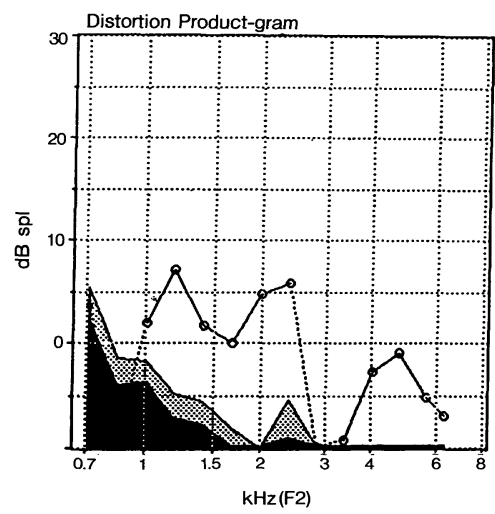

左

図 $4 \mathrm{OAE}$ 検査での各周波数域 DPOAE echo power

〈蝸電図〉
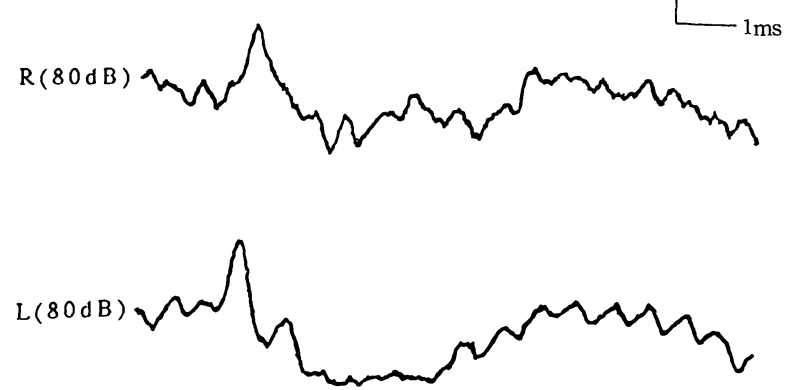

$\langle A B R\rangle$
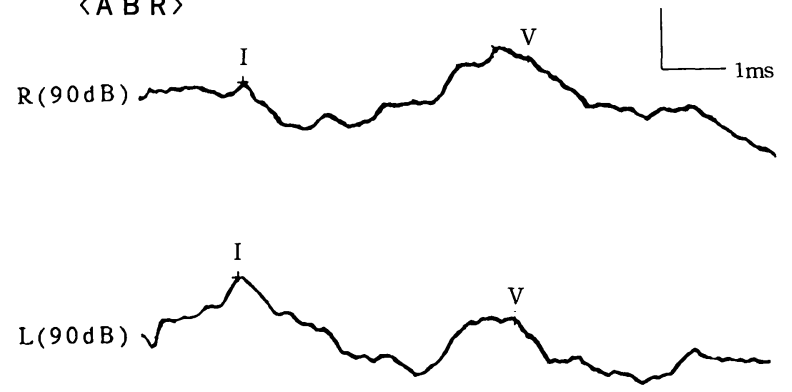

図 $5 \mathrm{ECoG}$ と $\mathrm{ABR}$ 検査の反応波形

定的であった．左側では， $\mathrm{AP} \cdot \mathrm{SP}$ ともに正常反応を 示していた。

7 ) 聴性脳幹反応 (ABR) 検査 : 6 月 20 日施行時の 90 $\mathrm{dB} \mathrm{nHL}$ クリック刺激にて得られた反応波形を示す(図 5 ). 左右ともに, I 波から V波までの各波の分離があ ク， I 〜 V 波間隔もともに $4.4 \mathrm{msec}$ と正常範囲内であ
った.

8 ）中間潜時反応 (MLR) 検査：6 月26日施行時， 90 $\mathrm{dB} \mathrm{nHL}$ クリック刺激にて得られた MLR 反応では, 左 右ともに, No・Po・Naは出現していたが，Paは消失 しており確認できなかった。

9 ) 頭頂部緩反応 (SVR) 検査：6 月26日施行時, 左 右ともに，75 dB nHL クリック刺激においても， N1 ・ P1・N2 は認められなかった。

10）電気眼振計 $(E N G)$ 検查 : カロリ一刺激において 半規管機能低下 $(\mathrm{CP}) \cdot$ 眼振方向優位性 (DP) ともに陰性 であった。

\section{考察}

本症例の両側感音性難聴について, 聴覚野梗塞側の対 側となる左側では，発症初期には純音聴力検査で䆍(ス ケールアウト)を示していたが，その後，急速に回復し 発症 1 カ月半後の 8 月 1 日には平均聴力レベル $25 \mathrm{~dB}$ となった。一方, 聴覚野梗塞側の同側である右側は, 発 症初期には, 平均 $42.5 \mathrm{~dB}$ の中等度感音性難德を示し, その後の回復は緩徐な時間経過で進行して, 正常化に約 3 ４ カ月を要した. 後述するように，サルを用いた一 側聴覚野への器質的病巣作製実験に括いて, 対側耳の純 音聴力は一時的に高度低下を示すが，その後，急速に回 復する4). 本症例は，七トに执いても，一側性皮質性難 聴の初期には, サルでの実験と同様に, 高度の一側性(対 側) 感音性難聴が存在することを示唆するものである. この純音聴力の回復機構は不明であるが, 回復過程は急 速に進むことから，純音聴力の低下を確認できるのは発 
症初期に限られ，一般的に認識されているように，皮質 性難聴での純音聴力域值はほぼ正常であると報告される ことになるのであろう

左側の難聴に関して，純音聴力検査以外では，ABR - $\mathrm{ECoG} \cdot \mathrm{OAE}$ 検査上何ら異常は認められず，語音聴 力検査に拉ける最高明瞭度の高度低下が継続して観察さ れた. MRL 検査については，これまでの報告によれば， Po 潜時のみ延長し No から Pa までの波形は正常である もの5)，全く波形が消失したもの2)，など様々であるが， $\mathrm{Pa}$ 以降の波が欠如する症例が多(3)6)。 $\mathrm{Pa}$ 以降の波は Heschl 脳回に打ける 1 次・2 次聴覚野より発生すると されて扣り7), 本症例の MRL 所見のように，聴覚野の 広範な梗塞により $\mathrm{Pa}$ 以降の波が消失するのは, 病態生 理学的に当然の結果であると考えられる. SVR 検査に 関しても，本症例を含めて，汪とんどの症例で反応の消 失が報告されている. 以上の検査所見より判断し，左側 難聴については，大脳皮質聴覚野の障害による皮質性難 聴によるものと考察した。

右側の難聴に関しては，ABR 波形は正常であったが $\mathrm{ECoG}$ 検査では AP 潜時の延長と AP 振幅の軽度低下を 認め, また, OAE 検査でも total echo power の軽度低 下があることから，梗塞時の右側内耳への血流障害など を誘因とする内耳性難聴が主たる成分と推察するが，皮 質性難聴の要素を完全に否定するものではない.

これまで，一側性聴覚野の梗塞による皮質性難聴にお。 ける，聴力の変化に関して，十分な検討はなされていな い. 大脳皮質は，言語に関しては優位側・非優位側を有 しており，非優位側の皮質性障害においては，純音聴力 は正常, 語音弁別も正常であるが1), 歪語音・断続語音 の弁別が困難であったり ${ }^{8)}$ ，方向弁別の低下 ${ }^{9)}$ が観察さ れるとの報告はある。一方，優位側の皮質性難聴におい ては, 純音聴力に関しては正常でも, 語音聴力に関して, 障害の程度により不全失語10) から聴覚失認や純粋語䆍11) まで様々な報告がある。語音聴力では，聴覚野の病巣側 の対側において，最高明瞭度がより高度に低下すること， すなわち交叉優位性が認められるのが特徵とされてい $ろ^{12)}$. 本症例にても, 梗塞側の対側の左側にて最高明 瞭度が25〜35\%と，右側の $80 \%$ 前後に比べて有意に低下 している.もし，前述したよらに，言語の聴取が一側の 聴覚野, つまり言語中枢の優位側皮質でのみ認知されて いるなら，このような交叉優位性は生じない。すなわち， 優位側皮質側の障害により語音聴取能は低下するが，非
優位側皮質の障害では低下しないこととなる．本症例は， 右利さであり，詳細な検討はなされていないが，言語中 枢の優位側は左側と推定される. 従って, 非優位側の右 側聴覚野での梗塞によって, 聴覚失認や純粋語壟など言 語聴取能の廃絶は認められないまでも, 高度の語音聴取 能の低下が発症することを強く示唆するものである。

大脳皮質聴覚野は，両側の側頭葉の横側頭回 (Heschl 脳回)に存在し，一側の内耳より皮質への投射は両側性 であるため，皮質聴覚野が両側性に高度に障害されては じめて, 純音聴力に低下が認められるとされ, 一側性の 皮質性障害ではわずかな純音聴力の変化しかおこりえな いと報告されてきた1〜3)。ヒトに拈ける一側性の皮質性 障害に拉いて, 唯一, 純音聴力の低下に言及したのは Karp ら ${ }^{13)}$ で, 一側性脳障害による19例の片麻痺患者中 10例で, 皮質性障害の対側の純音聴力の域值が有意に上 昇したと報告している.

動物実験でも，ネコを用いた一側の皮質聴覚野の破壊 実験では，対側の純音聴力の低下は否定的であった ${ }^{14)}$. ところが，最近になって，Heffner ら4)が訓練した日本 ザルを用いて, 一側の 1 次・ 2 次聴覚野の除去手術を施 行した後, 対側の純音聴力を測定したところ, 手術直後 には高周波数領域を中心にして純音聴力の著明な低下が 観察されるが，3〜 5 週以内に急速に回復することを確 認し報告した. 彼らは, 考察の中で, ヒトの一側性の皮 質性障害において, 純音聴力の低下が確認されにくい理 由として，1) 軽度の皮質性障害では, 高度な感音性難 聴は発症しにくく，患者本人が難聴を自覚せず，従って， 難聴の検索がなされないこと，2）高度の皮質性障害で は，救命などが優先し，難聴に対する聴覚検査が，発症 よりかなり時間が経過した後に施行されることになり， 発症初期には存在する一側性 (対側)の感音性難聴を確認 できないことなどをあげている.Heffner ら4)は，サル とヒトの聴覚野では, 解剖学的・生理学的に類似した構 成要素を有していることから，ヒトの一側性皮質性難聴 に掞いても，サルと同様に，対側の純音聴力の低下は生 じらると考察していた.

ヒトに打ける皮質聴覚野の障害は, 梗塞・出血などの 血流障害もしくは脳腫瘍によるものであり, サルの動物 実験に拈ける物理的破壞によるものと本質的に異なって おりまたヒトとサルの聴覚野の機能的・構造的な違い も存在すると考えられ，動物実験での結果をそのまま七 トに当てはめることは必ずしも適当ではない。しかしな 
がら，本症例で認められた皮質性障害側の対側に優位な 感音性難聴の発症および急速な回復は, Heffner ら ${ }^{4)}$ の 報告した実験結果と極めて一致して抢り，興味深い．

大脳皮質聴覚野の障害に护ける聴力の変化については, その発症機序执よび回復機構いずれも十分には解明され ていない，特に，一側性の皮質性障害において，純音聴 力に低下が認められるかどらかについて，今後症例を重 ね検討していく必要がある. 本症例にて観察されたよう に，皮質性障害の発症初期に拈いては，その障害が高度 な場合, 対側に純音聴力の低下を来たす可能性が強く示 唆されることから，皮質性難聴の発症をごく初期より予 測し，早期に純音・語音聴力検査などにより診断するよ ら努力する必要がある.

$$
\text { まとめ }
$$

1 ）右側大脳皮質聴覚野の梗塞による皮質性難聴の 1 症例を報告した。

2 ) 純音聴力検査にて，梗塞の対側である左側は，発 症初期には䆍を示し，その後，急速に $25 \mathrm{~dB}$ 前後まで 回復した。しかしながら, 語音聴力検査では最高明瞭度 の十分な回復はなく，25～35\%の低值で固定した.

3 ）梗塞の同側では, 純音聴力検査では, 発症初期に 中等度の感音性難聴を示し, 回復は緩徐で, $3 \sim 4$ カ月 で正常化した。一方, 語音聴力検査では, 最高明膫度 80 \%前後の良好な語音聴取能を維持していた。

4 ）高度の一側性皮質性障害に抢いて，少なくとも， その発症初期には, 障害側の対側の純音聴力および語音 聴力の両方に高度障害が存在し, 純音聴力は早期に回復 するものの, 語音聴力の障害は回復困難で, 長期間を経 ても残存するものと推察された.

\section{参考文献}

1 ）舩坂宗太郎：皮質損傷で龍になり得るか. 精神医学 25 : 345 349, 1983.

2) Graham J, Greenwood R and Lecky B : A case report and review of the literature. J Neurol Sci $48: 35 \sim 49,1980$.
3 ) Tanaka Y, Kamo T, Yoshida M, et al : So-called cortical deafness. Brain $114: 2385 \sim 2401,1991$.

4) Heffner HE and Heffner RS : Unilateral auditory cortex ablation in macaques results in a contralateral hearing loss. J Neurophysiol 62 : 789 801, 1989.

5 ) Bahls FH, Chatrian GE and Mesher RA : A case of persistent cortical deafness; clinical, neurophysiologic, and neuropathologic observations. Neurology 38 : 1490 1493, 1988.

6) Mendez MF and Geehan Jr GR : Cortical auditory disorders ; clinical and psychoacoustic feature. J Neurol $51: 1 \sim 9,1988$.

7 ) Liegeois-Chauvel C, Musolino A, Badier JM, et al : Evoked potentials recorded from the auditory cortex in man; evaluation and topograph of the middle latency components. Electroenceph Clin Neurophysiol $92: 204 \sim 214$, 1994.

8 ) Jerger $\mathbf{J}$ : Observations on auditory behavior in lesion of the central auditory pathways. Arch Otolaryngol $71: 710$ $\sim 806,1960$.

9 ) Sanchez-Longo LP and Foster FM : Clinical significance of impairment of sound localization. Neurology $8: 119 \sim$ $125,1958$.

10) Jerger J, Weiker $N$, Sharbrough F, et al : Bilateral lesions of the temporal lobe; a case study. Acta Otolaryngol Suppl (Stockh) $258: 1 \sim 51,1969$.

11) Gazzaniga MS, Glass AV, Sarno MT, et al : Pure word deafness and hemispheric dynamics ; a case history. Cortex $9: 136 \sim 143,1973$.

12）佐藤恒正: 語音弁別能の障害. 精神医学 $25: 363 \sim 371$, 1983.

13) Karp E, Belmont I and Birch HG : Unilateral hearing loss in hemiplegic patients. J Nerv Ment Dis $148: 83 \sim 86,1969$.

14) Cranford JL and Igarashi $M$ : Effects of auditory cortex lesions on temporal summation in cats. Brain Res $136: 559$ $\sim 564,1977$.

/原稿受付 : 平成 8 年12月 27 日 原稿採択: 平成 9 年 4 月 2 日 別刷請求先 : 日比野浩 于565 吹田市山田丘2-2 大阪大学医学部耳鼻咽喉科学教室) 